\title{
Characteristics of Phosphorus in Sediments in Drainage Canals in Paddy-Field Districts around Lake Biwa
}

\author{
Daichi IWASAKI*, Takehide HAMA*, Katsuyuki OSUGA**, Sho SUGIYAMA* \\ * Graduate School of Agriculture, Kyoto University, Kyoto 606-8502, Japan \\ **Shiga Prefectural Government, Shiga 520-8577, Japan
}

\begin{abstract}
Phosphorus (P) is a limiting factor of eutrophication in many lakes. Paddy-field districts are major non-point sources of $\mathrm{P}$; water pollution prevention measures are to be implemented in these districts. However, sediment in drainage canals has a large P buffering capacity and can release $\mathrm{P}$ to the water column when input of $\mathrm{P}$ from paddy fields is reduced. Therefore, it is necessary to evaluate the amounts of $\mathrm{P}$ in the sediment in drainage canals. In this study, the sediments in drainage canals in paddy-field districts around Lake Biwa were investigated. The amounts and fractions of $\mathrm{P}$ in the sediments during both the irrigation period and the non-irrigation period were analyzed. Results showed that the mean value of total $\mathrm{P}$ in the sediment was $0.6 \mathrm{~g} / \mathrm{kg}$ in both periods, but total $\mathrm{P}$ in non-irrigation periods tends to be greater than that during irrigation periods for each site in the study. Furthermore, over $70 \%$ of total $\mathrm{P}$ was inorganic on the average. Moreover, the fractions of organic and inorganic $\mathrm{P}$ exhibited seasonal variability. The potential contribution of water-extractable $\mathrm{P}$ in the sediment to total $\mathrm{P}$ in drainage water increased from June to November.
\end{abstract}

Keywords: drainage canal, paddy field, phosphorus, sediment

\section{INTRODUCTION}

Rice paddy fields, which use about $60 \%$ of the total water resources of Japan, are the most important non-point sources of phosphorus $(\mathrm{P})$. The effluent load of $\mathrm{P}$ from a paddy-field district has large impacts on downstream ecosystems: eutrophication, algal blooms, and freshwater red tides.

Recently, increased interest in environmental problems has led to the implementation of many environmentally friendly farming practices. Paddy-field-scale practices include reducing the amount of chemical fertilizer used by applying slow-release fertilizer (Choi and Nelson, 1996; Fan and Li, 2010). District-scale practices include restructuring of vegetation and the reuse of drainage water through irrigation recycling, which can reduce the load of suspended solids (SS) (Hama et al., 2010) and nutrients (Takeda et al., 1997; Feng et al., 2004, 2005; Takeda and Fukushima, 2006). However, increased implementation of these measures may cause ponding of water with high SS and P loads in drainage canals. For example, when water is reused, water with high SS load flows in drainage canals. As a result, $\mathrm{P}$ bound or adsorbed to suspended solids may accumulate in the bottom of these drainage canals. Reduction of effluent loads in the canals is important because the canals may act as sources of $\mathrm{P}$ when water flowing into the drainage canals contains no P. In particular, it is essential for the appropriate management of drainage canals to quantify the amount of $\mathrm{P}$ in the sediments because $\mathrm{P}$ tends to be adsorbed or desorbed to sediments easily. Christophoridis and Fytianos (2006) revealed that the rates of release of $\mathrm{P}$ from lake sediment increased under reductive conditions and high $\mathrm{pH}$ values. It is reported that lake sediment $\mathrm{P}$ release

Address correspondence to Daichi Iwasaki, Graduate School of Agriculture, Kyoto University

Email: iwasaki.daichi.66s@st.kyoto-u.ac.jp

Received May 9, 2012, Accepted September 21, 2012. 
mainly relates to $\mathrm{P}$ bound to iron and aluminum, and total organic carbon (Pant and Reddy, 2001; Wang et al., 2005; Dong et al., 2011). However, there is little research to date that has investigated the amount of $\mathrm{P}$ in drainage canals. Therefore, in this paper, we clarified the amount and fraction of $\mathrm{P}$ in the sediments in drainage canals in low-lying paddy-field districts.

\section{MATERIALS AND METHODS}

\section{Study sites}

We investigated 6 paddy-field districts around Lake Biwa in Shiga Prefecture, Japan (Fig. 1). Lake Biwa is the largest lake in Japan and the most important water resource for the Kinki region, which includes Osaka and Kyoto. Around Lake Biwa, two main types of irrigation practices, namely, lake water irrigation and river water irrigation are employed.

An outline of each study site is shown in Table 1. Mean annual temperature around all sites is $14^{\circ} \mathrm{C}$. Most sites have separate irrigation and drainage canals, except St. F. Drainage canals are considered to have wall lining when only the walls are lined with concrete, while considered to have concrete lining when both the walls and the bottom are lined with concrete.

We focused on two periods, irrigation period and non-irrigation period. During the irrigation period, from late April to the middle of September, the irrigation water is supplied to paddy fields. As a result, highly loaded water may flow into the drainage canal. During the non-irrigation period, less P containing water may flow or pond in the drainage canal. Therefore, we investigated the study districts in June (irrigation period) and in November (non-irrigation period) of 2011.

\section{Phosphorus measurement in the sediments and paddy soils}

Sediments in drainage canals and paddy soils in nearby fields were sampled in June and November 2011 at each of the study sites.

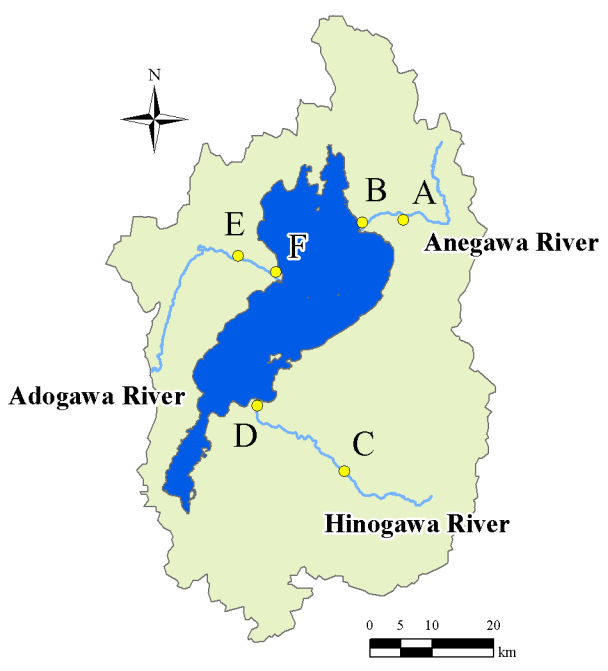

Fig. 1 - Study sites. 
Table 1 - Outline of study sites and canals.

\begin{tabular}{|c|c|c|c|c|c|}
\hline St. & \multicolumn{2}{|c|}{ District } & \multicolumn{2}{|c|}{$\begin{array}{c}\text { Water Catchmen } \\
\text { Area [ha] }\end{array}$} & $\begin{array}{ll}\text { nent } & \text { Mean Annual } \\
& \text { Rainfall [mm }]^{\mathrm{a}}\end{array}$ \\
\hline A & Enoki Town, $\Gamma$ & gahama City & $35^{\circ} 24^{\prime} \mathrm{N}, 136^{\circ} 18^{\prime}$ & 9.4 & \multirow{2}{*}{1,800} \\
\hline B & Yagihama Town & Nagahama City & $35^{\circ} 24^{\prime} \mathrm{N}, 136^{\circ} 13^{\prime}$ & 13.0 & \\
\hline $\mathrm{C}$ & Shimo-Aso Town, & igashi-Ohmi City & $35^{\circ} 02^{\prime} \mathrm{N}, 136^{\circ} 11^{\prime}$ & 48.7 & \multirow{2}{*}{1,600} \\
\hline $\mathrm{D}$ & Nomura Town, Oh & i-Hachiman City & $35^{\circ} 08^{\prime} \mathrm{N}, 136^{\circ} 02^{\prime}$ & 7.9 & \\
\hline E & Adogawa Town, & akashima City & $35^{\circ} 21^{\prime} \mathrm{N}, 136^{\circ} 00^{\prime}$ & 9.1 & \multirow{2}{*}{2,500} \\
\hline $\mathrm{F}$ & Adogawa Town, & akashima City & $35^{\circ} 20^{\prime} \mathrm{N}, 136^{\circ} 04^{\prime}$ & 52.5 & \\
\hline St. & Nearby River & Location $^{\mathrm{b}}$ & $\begin{array}{c}\text { Irrigation } \\
\text { Water } \\
\end{array}$ & Canals $^{\mathrm{c}}$ & $\begin{array}{c}\text { Lining on } \\
\text { Drainage Canal } \\
\end{array}$ \\
\hline A & Anegawa River & Upstream $(9 \mathrm{~km})$ & River & Separated & Wall lining \\
\hline B & Anegawa River & Downstream & Lake & Separated & Wall lining \\
\hline $\mathrm{C}$ & Hinogawa River & Upstream $(23 \mathrm{~km})$ & River & Separated & Concrete lining \\
\hline $\mathrm{D}$ & Hinogawa River & Downstream & Lake & Separated & Wall lining \\
\hline $\mathrm{E}$ & Adogawa River & Upstream $(9 \mathrm{~km})$ & River & Separated & Concrete lining \\
\hline $\mathrm{F}$ & Adogawa River & Downstream & River & Not-separated & No lining \\
\hline
\end{tabular}

Sediment samples were classified as those corresponding to upper, middle, and lower layers. The upper layer extended to about $1 \mathrm{~cm}$ depth from the sediment surface, the middle layer from around $1 \mathrm{~cm}$ to $5 \mathrm{~cm}$, and the lower layer from around $5 \mathrm{~cm}$ to $10 \mathrm{~cm}$ depth. At St. E, however, because of low sedimentation rates, E-L (the lower layer of the St. E sample) could not be sampled. Samples were taken to the laboratory in airtight bags and kept in cool conditions. Then, samples were dried in a refrigerator and sieved through a $125-\mu \mathrm{m}$ sieve (Ruttenberg, 1992) wherein the waste material, gravel, and other constituents over $2 \mathrm{~mm}$ in diameter were removed.

Sediments and paddy soils were analyzed for ignition loss, weight ratio of particles smaller than $125-\mu \mathrm{m}$, total P (TP), and some P fractions. Analyzable forms of P are divided into the following fractions: total inorganic $\mathrm{P}$ (TIP); water-extractable $\mathrm{P}$ (WE-P); $\mathrm{P}$ bound to iron, aluminum, and calcium carbonate (Fe-P, Al-P, and $\mathrm{CaCO}_{3}-\mathrm{P}$, respectively); $\mathrm{P}$ including detrital apatite (Detrital-P); and total organic $\mathrm{P}$ (TOP). In this study, TIP was extracted from oven-dried sediments and paddy soils using $1 \mathrm{M} \mathrm{HCl}$ solution for $16 \mathrm{~h}$ and $\mathrm{TP}$ was extracted using the same method after ignition at $550^{\circ} \mathrm{C}$ for $2 \mathrm{~h}$. The WE-P and Fe-P + Al-P fractions were dissolved out of naturally dried sediments and paddy soils: WE-P was determined to be $\mathrm{PO}_{4}-\mathrm{P}$ dissolved out using distilled water for $2 \mathrm{~h}$, and Fe-P + Al-P was determined to be the difference between $\mathrm{PO}_{4}-\mathrm{P}$ extracted by $1 \mathrm{M}$ sodium hydroxide $(\mathrm{NaOH})$ solution for $16 \mathrm{~h}$ and WE-P.

After extraction, all these samples were filtrated through a $0.45-\mu \mathrm{m}$ cellulose acetate membrane filter. Phosphorus concentration measurements were made using a spectrophotometer (UV-1200; Shimadzu Corp., Kyoto, Japan) using the molybdenum blue method. Furthermore, the $\mathrm{CaCO}_{3}-\mathrm{P}+$ Detrital-P fraction was calculated as the 
difference between TIP and $\mathrm{PO}_{4}-\mathrm{P}$ extracted using $\mathrm{NaOH}$. Total OP was calculated by subtracting TIP from TP. Traditionally, fractionation of $\mathrm{P}$ has employed a sequential extraction method (SEDEX, Ruttenberg, 1992).

\section{Phosphorus measurement in the drainage water}

The water in the drainage canals was sampled at the same time as the sediments and soils. These sampled drainage water were analyzed for TP, dissolved total P (DTP), and phosphate $\mathrm{P}\left(\mathrm{PO}_{4}-\mathrm{P}\right)$. Dissolved $\mathrm{P}$ was distinguished by filtering the sample with a $1-\mu \mathrm{m}$ filter prior to analysis. Total $\mathrm{P}$ and DTP concentrations were measured by a spectrophotometer using the molybdenum blue method after potassium-peroxydisulfate digestion, while $\mathrm{PO}_{4}-\mathrm{P}$ concentration was measured by the molybdenum blue method.

\section{RESULTS AND DISCUSSION}

\section{Weight ratio of particles smaller than $125 \mu \mathrm{m}$}

Table 2 shows the ratios of the weights of sediments and paddy soils that were sampled in November and passed through a $125-\mu \mathrm{m}$ sieve to the total weight of the sediments and paddy soils $(<2 \mathrm{~mm}$ sieve)

The weight ratio of the sediment ranged from 0.17 to 0.93 , and the average of all stations and layers was 0.70 . Compared to the trends for paddy soils, those of sediments differ remarkably among sites. Variations in weight ratios were small at St. B, D, E, and $\mathrm{F}$, with a range of less than 0.08 . This was particularly noticeable at St. F, where it was assumed to be a result of the lack of separation of the canals and the lack of lining. In contrast, at St. A and St. C, the weight ratios were three or four times higher in lower layers than in upper layers. This is thought to reflect not the weight ratio of paddy soil, which is a main origin of the sediment, but the physical conditions such as current velocity. At St. A, a high current velocity of $55 \mathrm{~cm} / \mathrm{s}$ was observed in September (after harvesting), which may have resulted in the removal of fine fractions in the top layer. In addition, at St. C and St. E, of which the drainage canal receives water from the outside even during the non-irrigation period, the base flow of more than $2 \mathrm{~cm} / \mathrm{s}$ caused the removal in the top layer (St. C) and prevented sedimentation of fine particles (St. E).

Table 2 - Weight ratio of particles smaller than $125 \mu \mathrm{m}$ and water depth and current velocity in the drainage canals in November.

\begin{tabular}{|c|c|c|c|c|c|c|c|}
\hline \multirow{3}{*}{ St. } & \multicolumn{4}{|c|}{ Sediment $^{\mathrm{a}}$} & \multirow{3}{*}{ Paddy soil } & \multirow{3}{*}{$\begin{array}{c}\begin{array}{c}\text { water } \\
\text { depth }\end{array} \\
\mathrm{cm}\end{array}$} & \multirow{3}{*}{$\begin{array}{c}\begin{array}{r}\text { current } \\
\text { velocity }\end{array} \\
\mathrm{cm} / \mathrm{s}\end{array}$} \\
\hline & \multicolumn{3}{|c|}{ Layer } & \multirow{2}{*}{ Average } & & & \\
\hline & Upper & Middle & Lower & & & & \\
\hline A & 0.31 & 0.67 & 0.86 & 0.73 & 0.67 & 13 & 0 \\
\hline B & 0.53 & 0.55 & 0.48 & 0.51 & 0.85 & 26 & 2 \\
\hline $\mathrm{C}$ & 0.17 & 0.55 & 0.67 & 0.57 & 0.70 & 16 & 2 \\
\hline $\mathrm{D}$ & 0.85 & 0.78 & 0.77 & 0.78 & 0.64 & NS & NS \\
\hline $\mathrm{E}$ & 0.45 & 0.43 & $\mathrm{NS}^{\mathrm{b}}$ & 0.44 & 0.74 & 12 & 3 \\
\hline $\mathrm{F}$ & 0.85 & 0.87 & 0.93 & 0.90 & 0.91 & 11 & 0 \\
\hline $\begin{array}{l}{ }^{\mathrm{a}} 100 \\
\text { rem } \\
\text { low }\end{array}$ & .00 ) rep & ts a sam! & $\begin{array}{l}\mathrm{m} \text { whicl } \\
\text { conside } \\
\mathrm{cm} \text {, res1 }\end{array}$ & $\begin{array}{l}\text { aste and ot } \\
\text { the thickn } \\
\text { ively. }\end{array}$ & er particles o & $\begin{array}{l}\text { er } 2 \mathrm{mn} \\
\text { er, midc }\end{array}$ & $\begin{array}{l}\text { have been } \\
e \text {, and }\end{array}$ \\
\hline
\end{tabular}


Although it has not been possible to specify all factors affecting the ratios, these results show that the weight ratio of the sediment is strongly affected by the conditions in the drainage canal.

\section{Quantification of phosphorus and its fractions in the sediments}

Figure 2 shows TP in June and November for every station. Average values of TP were $0.62 \mathrm{gP} / \mathrm{kg}$ (range: $0.14-1.19 \mathrm{gP} / \mathrm{kg}$ ) in June and $0.67 \mathrm{gP} / \mathrm{kg}$ (range: $0.24-1.94 \mathrm{gP} / \mathrm{kg}$ ) in November. For both periods and in all stations, TP values in the sediments were higher in the upper layer than in the lower layer. TP in paddy soils tends to be similar to that of the upper sediment layer, perhaps as a result of accumulation of phosphorus from drainage water or SS in the water on the surface of the sediments. Therefore, sediment in the drainage canals contained large amount of $\mathrm{P}$ depending on the amount of $\mathrm{P}$ in the paddy soil. In addition, $\mathrm{P}$ is easy to dissolve in lower layers, where reducing conditions are more prevalent. The sediments in the lower layer show black or gray color, indicating that they are under reducing conditions.

Total $\mathrm{P}$ was greater in November than in June for all samples, with the exception of B-M (middle layer of the sample from St. B), E-M, F-M, and F-L. In other words, TP tended to be higher in the non-irrigation period.

Table 3 shows the quantities of the various $\mathrm{P}$ fractions that make up TP of the sediment. The sum of $\mathrm{CaCO}_{3}-\mathrm{P}+$ Detrital-P, Fe-P + Al-P, and WE-P is TIP, and the sum of TOP and TIP is TP. The average was calculated considering the thickness of each layer in the same way as the weight ratio. The average amount of TOP was $0.14 \mathrm{gP} / \mathrm{kg}$ in June and $0.17 \mathrm{gP} / \mathrm{kg}$ in November. Total IP was $0.47 \mathrm{gP} / \mathrm{kg}$ in June and $0.50 \mathrm{gP} / \mathrm{kg}$ in November on the average. The amounts of all fractions tend to decrease from the upper layer to the lower layer, both in June and in November.

Figure 3 shows the proportions of $\mathrm{P}$ fractions in paddy soil and sediment (average and by layer). In both June and November, TIP accounts for more than $70 \%$ of TP in the

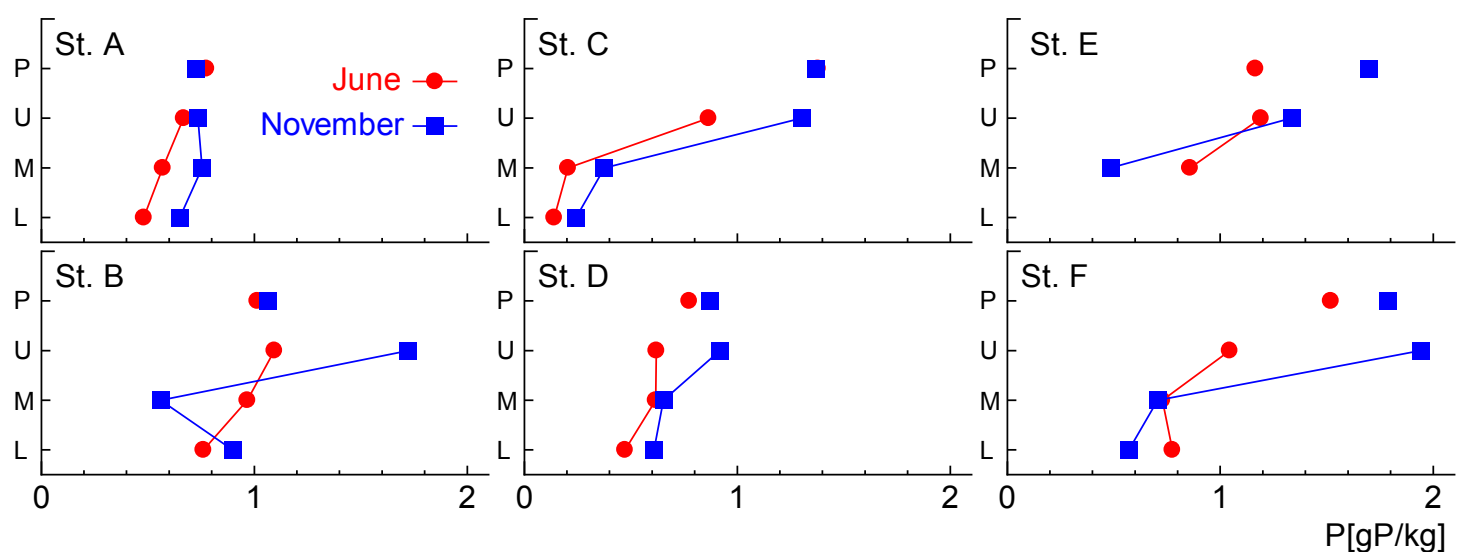

Fig. 2 - Site-specific TP in June and November. The plots show the amount of TP on the horizontal axes and the types of sample on the vertical axes: paddy soil $(\mathrm{P})$, upper layer (U), middle layer (M), and lower layer (L). 
Table 3 - Quantities of TP and phosphorus fractions.

\begin{tabular}{|c|c|c|c|c|c|c|c|c|c|}
\hline \multirow[t]{2}{*}{ St. } & \multirow[t]{2}{*}{ Layer } & \multicolumn{2}{|c|}{ TOP } & \multicolumn{2}{|c|}{$\begin{array}{l}\mathrm{CaCO}_{3}-\mathrm{P} \\
\text { Detrital-P }\end{array}$} & \multicolumn{2}{|c|}{$\begin{array}{l}\text { Fe-P } \\
\text { Al-P }\end{array}$} & \multicolumn{2}{|c|}{ WE-P } \\
\hline & & Jun. & Nov. & Jun. & Nov. & Jun. & Nov. & Jun. & Nov. \\
\hline \multirow{3}{*}{ A } & Upper & 0.17 & 0.16 & 0.23 & 0.41 & 0.27 & 0.16 & 0.01 & 0.02 \\
\hline & Middle & 0.15 & 0.32 & 0.19 & 0.27 & 0.22 & 0.16 & 0.01 & 0.01 \\
\hline & Lower & 0.16 & 0.12 & 0.09 & 0.40 & 0.24 & 0.13 & 0.01 & 0.01 \\
\hline \multirow{3}{*}{ B } & Upper & 0.18 & 0.24 & 0.15 & 0.71 & 0.77 & 0.78 & 0.00 & 0.00 \\
\hline & Middle & 0.13 & 0.09 & 0.20 & 0.30 & 0.64 & 0.17 & 0.01 & 0.00 \\
\hline & Lower & 0.14 & 0.12 & 0.17 & 0.41 & 0.45 & 0.37 & 0.00 & 0.00 \\
\hline \multirow{3}{*}{$\mathrm{C}$} & Upper & 0.12 & 0.25 & 0.06 & 0.52 & 0.69 & 0.53 & 0.02 & 0.01 \\
\hline & Middle & 0.02 & 0.07 & 0.03 & 0.15 & 0.15 & 0.16 & 0.01 & 0.00 \\
\hline & Lower & 0.02 & 0.06 & 0.02 & 0.10 & 0.10 & 0.09 & 0.01 & 0.00 \\
\hline \multirow{3}{*}{ D } & Upper & 0.25 & 0.38 & 0.02 & 0.28 & 0.35 & 0.25 & 0.00 & 0.02 \\
\hline & Middle & 0.19 & 0.27 & 0.04 & 0.19 & 0.39 & 0.19 & 0.02 & 0.02 \\
\hline & Lower & 0.15 & 0.22 & 0.01 & 0.18 & 0.32 & 0.20 & 0.00 & 0.02 \\
\hline \multirow{2}{*}{ E } & Upper & 0.36 & 0.45 & 0.11 & 0.47 & 0.72 & 0.41 & 0.01 & 0.01 \\
\hline & Middle & 0.24 & 0.21 & 0.05 & 0.13 & 0.57 & 0.15 & 0.00 & 0.01 \\
\hline \multirow{3}{*}{$\mathrm{F}$} & Upper & 0.22 & 0.41 & 0.13 & 0.77 & 0.70 & 0.76 & 0.00 & 0.01 \\
\hline & Middle & 0.16 & 0.13 & 0.12 & 0.37 & 0.45 & 0.21 & 0.00 & 0.01 \\
\hline & Lower & 0.18 & 0.12 & 0.17 & 0.29 & 0.43 & 0.16 & 0.01 & 0.00 \\
\hline \multicolumn{2}{|c|}{ Average } & 0.14 & 0.17 & 0.10 & 0.28 & 0.37 & 0.21 & 0.01 & 0.01 \\
\hline
\end{tabular}

The values of the fractions are shown as the weight per unit oven-dried sediment (gP/kg).

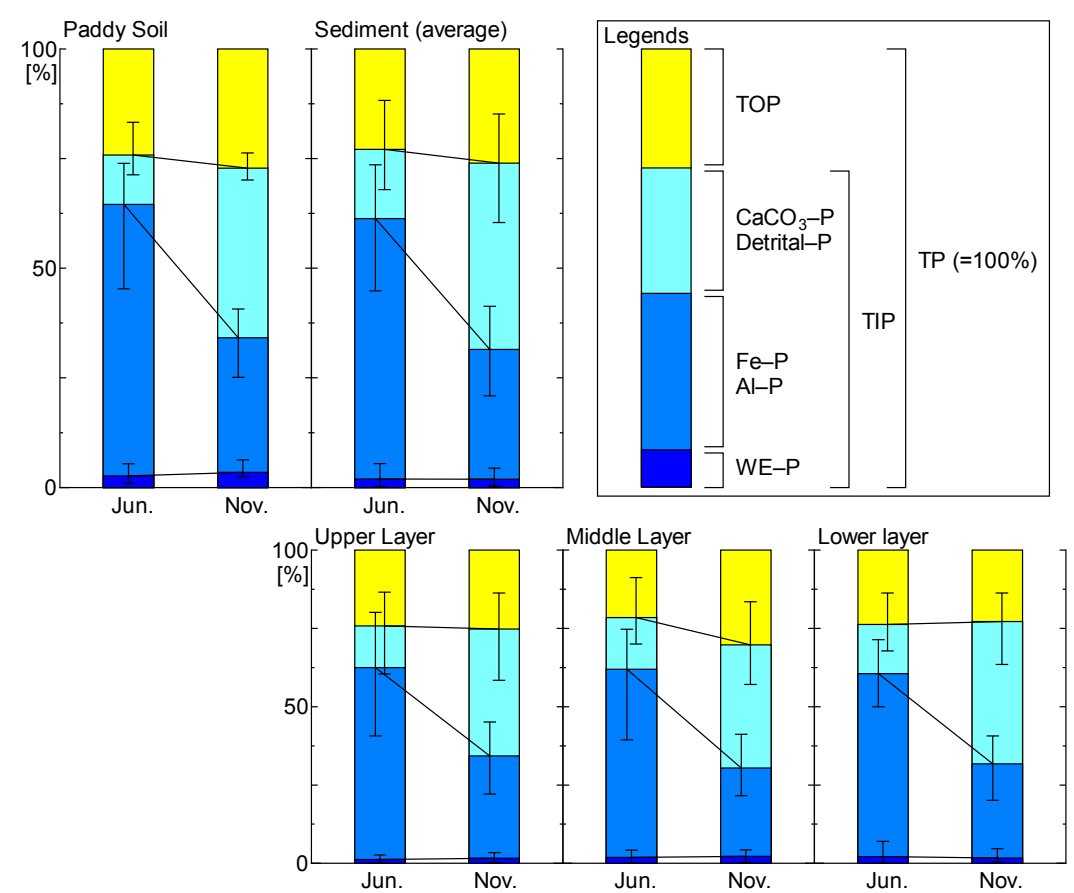

Fig. 3 - Proportion of phosphorus fractions to TP. The error bars indicate upper and lower limits among all sites. The average was calculated considering the thickness of each layer.

sediment on the average. The mean proportion of $\mathrm{CaCO}_{3}-\mathrm{P}+$ Detrital-P is $16 \%$ in June and $42 \%$ in November. The mean proportion of Fe-P + Al-P is $61 \%$ in June and $31 \%$ in November. The mean proportion of WE-P to TP is less than $2 \%$ on the average, in both 
June and November. On the other hand, the proportions of all fractions vary greatly among the sites. For example, in June, TIP of St. C accounts for $88 \%$ of TP, but that of St. D accounts for $68 \%$ of TP.

From June to November, the amount (Table 3) and the proportion (Fig. 3) of Fe-P + Al-P decreased while that of $\mathrm{CaCO}_{3}-\mathrm{P}+$ Detrital-P increased. However, there was a little difference in TIP, TOP, and WE-P between June and November. Therefore, it is suggested that seasonal variation of $\mathrm{P}$ in the sediment is mainly affected by the fractions of $\mathrm{CaCO}_{3}-\mathrm{P}+$ Detrital-P and Fe-P + Al-P.

\section{Influence of phosphorus in the sediment on the overlying drainage water}

Water-extractable $\mathrm{P}$, which is extracted by water containing no $\mathrm{P}$, is believed to indicate the quantity of $\mathrm{P}$ dissolved by drainage water containing no or low $\mathrm{P}$ without resulting in chemical changes such as in $\mathrm{pH}$ or ORP. Therefore, in order to evaluate the potential of the sediment to contribute $\mathrm{P}$, we calculated the potential WE-P in the overlying drainage water. The potential concentration of $\mathrm{P}$ released from the sediment, $C_{\text {sed }}$, can be estimated by the following equation:

$$
C_{\text {sed }}=(\mathrm{WE}-\mathrm{P}) \rho_{\mathrm{s}} V_{\mathrm{s}} / V_{\mathrm{d}}=(\mathrm{WE}-\mathrm{P}) \rho_{\mathrm{s}}(1-n) h_{\mathrm{sed}} / h_{\mathrm{d}}
$$

where WE-P is the amount of water-extractable $\mathrm{P}$ per unit sediment in the upper layer $(\mathrm{g} / \mathrm{kg}), \rho_{\mathrm{s}}$ is the density of soil $\left(\mathrm{kg} / \mathrm{m}^{3}\right) ; V_{\mathrm{s}}$ is the volume of the sediment $\left(\mathrm{m}^{3}\right) ; V_{\mathrm{d}}$ is the volume of overlying drainage water $\left(\mathrm{m}^{3}\right) ; h_{\text {sed }}$ is the depth of the sediment $(\mathrm{m}) ; h_{\mathrm{d}}$ is the depth of drainage water $(\mathrm{m})$; and $n$ is the porosity of the sediment. Here, we assigned a value of 2.65 to $\rho_{\mathrm{s}}$, which is a commonly used value for soil. Because we could not measure the porosities of the sediments in this study, the values of $0,0.25$ and 0.5 are assigned to $n$ to estimate the range of $C_{\text {sed. }}$

Figure 4 shows the ratios of $C_{\text {sed }}$ to TP concentration in drainage water $\left(C_{\mathrm{d}}\right)$. Because drainage water did not exist at St. D in November, this result is not shown. The ratios of $C_{\text {sed }}$ to $C_{\mathrm{d}}$ increased considerably from June to November at all sites except St. C. This

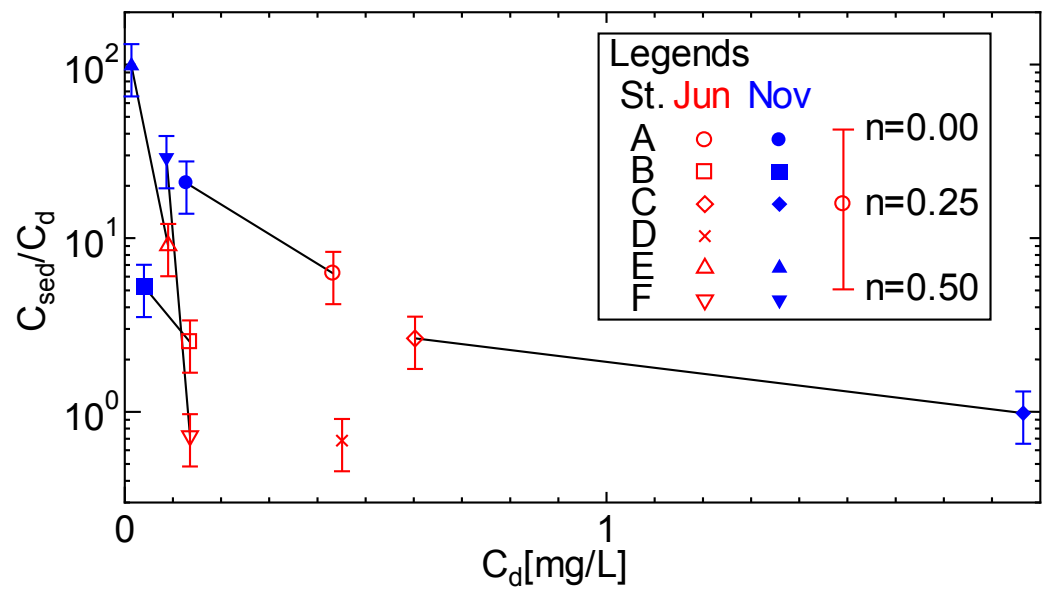

Fig. 4 - Contribution of water-extractable phosphorus to phosphorus in drainage water. 
may be because the drainage water in November contained less $\mathrm{P}$, which suggested that the influence of $\mathrm{P}$ in the sediments is greater in November than in June.

However, at St. C the percentage was decreased; this may be a result of the inflow into the drainage of domestic wastewater from the neighboring settlement, which has higher $\mathrm{P}$ concentration than the agricultural drainage water.

\section{CONCLUSIONS}

Results showed that sediment in the drainage canals contained significant amount of $\mathrm{P}$ depending on the amount of $\mathrm{P}$ in the paddy soil, although the weight ratio varied among paddy-field districts. The mean amounts of TP in the sediments were $0.62 \mathrm{gP} / \mathrm{kg}$ in June and $0.67 \mathrm{gP} / \mathrm{kg}$ in November, and TP in the sediments increased in November. The P in the sediment consisted mainly of inorganic P (over $70 \%$ of TP on the average). It implied that the seasonal variations of TP in the sediments are determined by those of specific $\mathrm{P}$ fractions: $\mathrm{CaCO}_{3}-\mathrm{P}$, Detrital-P, Fe-P, and Al-P. The contribution of $\mathrm{P}$ in the sediment to $\mathrm{P}$ in drainage water increased from June to November. Therefore, the fractions of $\mathrm{P}$ should also be considered when implementing water quality conservation measures.

\section{REFERENCES}

Choi J. M. and Nelson P. V. (1996) Developing a slow-release nitrogen fertilizer from organic sources: II. Using poultry feathers. J. Amer. Soc. Hort. Sci., 121(4), 634-638.

Christophoridis C. and Fytianos K. (2006) Conditions affecting the release of phosphorus from surface lake sediments. J. Environ. Qual., 35(4), 1181-1192.

Dong L., Yang Z. and Liu X. (2011) Phosphorus fractions, sorption characteristics, and its release in the sediments of Baiyangdian Lake, China. Environ. Monit. Assess., 179(1-4), 335-345.

Fan X. H. and Li Y. C. (2010) Nitrogen release from slow-release fertilizers as affected by soil type and temperature. Soil Sci. Soc. Am. J., 74(5), 1635-1641.

Feng Y. W., Yoshinaga I., Shiratani E., Hitomi T. and Hasebe H. (2004) Characteristics and behavior of nutrients in a paddy field area equipped with a recycling irrigation system. Agric. Water Manage., 68(1), 47-60.

Feng Y. W., Yoshinaga I., Shiratani E., Hitomi T. and Hasebe H. (2005) Nutrient balance in a paddy field with a recycling irrigation system. Water Sci. Technol., 51(3-4), 151-157.

Hama T., Nakamura K. and Kawashima S. (2010) Effectiveness of cyclic irrigation in reducing suspended solids load from a paddy-field district. Agric. Water Manage., 97(3), 483-489.

Japan Meteorological Agency (2011) Automated Meteorological Data Acquisition System (AMeDAS), http://www.jma.go.jp (accessed on April 5, 2012).

Pant H. K. and Reddy K. R. (2001) Phosphorus sorption characteristics of estuarine sediments under different redox conditions. J. Environ. Qual., 30(4), 1474-1480.

Ruttenberg K. C. (1992) Development of a sequential extraction method for different forms of phosphorus in marine sediments. Limnol. Oceanogr., 37(7), 1460-1482.

Takeda I. and Fukushima A. (2006) Long-term changes in pollutant load outflows and 
purification function in a paddy field watershed using a circular irrigation system. Water Res., 40(3), 569-578.

Takeda I., Fukushima A. and Tanaka R. (1997) Non-point pollutant reduction in a paddy-field watershed using a circular irrigation system. Water Res., 31(11), 2685-2692.

Wang S. R., Jin X. C., Pang Y., Zhao H. C., Zhou X. N. and Wu F. C. (2005) Phosphorus fractions and phosphate sorption characteristics in relation to the sediment compositions of shallow lakes in the middle and lower reaches of Yangtze River region, China. J. Colloid Interface Sci., 289(2), 339-346. 